\title{
Meaning in life and the experience of older people
}

\author{
By Peter Derkx*, Pien Bos*, Hanne Laceulle* E Anja Machielse*
}

\begin{abstract}
In this article, we introduce a general theory about meaning in life developed by our first author, and apply it to the context of ageing. The seven components of meaning distinguished by this theory - purpose, moral worth, selfworth, control, coherence, excitement and connectedness - are discussed in turn. After presenting the theory, we confront the seven components with extensive life narratives of two older men - in a first empirical qualitative exploration of how meaning dimensions appear in the life experiences of older people. This dialogue between theory and narrative is used to provide concretisation and clarification of the seven components, thereby enhancing the understanding of the theory, while at the same time suggesting possible refinements and directions for future exploration of meaning in life in the context of ageing.
\end{abstract}

Keywords: meaning in life, life course, narrative, lived experience, older people, ageing well.

* Peter Derkx, Pien Bos, Hanne Laceulle \& Anja Machielse. University of Humanistic Studies, Utrecht, The Netherlands 
International Journal of Ageing and Later Life

\section{Introduction}

This article is the result of an interdisciplinary cooperation that we have conducted in the context of a larger research programme titled "Ageing well" (Baars et al. 2013; Derkx et al. 2011). In 2008, this programme was initiated in response to what we observed as a relative lack of gerontological attention to the existential dimensions of the experience of ageing, in contrast to the much more dominant biomedical discourse about senescence (e.g. Kennedy et al. 2014; Olshansky et al. 2006; Sierra et al. 2009), and the economic/financial and social/critical discourse about population ageing (e.g. Baars et al. 2006; Bovenberg et al. 2015; Immergut et al. 2009; Reinhardt 2003; Zweifel et al. 1999). Older people are at a stage of life that increases the likelihood of being confronted with multiple losses (e.g. of loved ones, work and/or health, social roles). Such intense life events provoke existential questions and moral challenges that generate particular senses of (lack of) meaning (Hupkens et al. 2018).

In this article, we focus on the meaning dimensions of ageing. The aim of this article is to offer insight into the variety of experiences of meaning in life in the daily lives of older people who are confronted with age-related losses. To this end, the following research question is formulated: How do older persons find meaning in their daily lives? To answer this question, we introduce a general theory of meaning in life, formulated by Derkx (2011, 2013, 2015), comprehending different needs that should be fulfilled in order for the experience of meaning in life to emerge. After presenting the theory, we confront the seven needs with the narratives of two older men and explore how meaning dimensions appear in the life experiences of older people. This dialogue between theory and narratives is used to provide concretisation and clarification of the seven components, thereby enhancing the understanding of the theory, while at the same time suggesting possible refinements and directions for future exploration of meaning in life in the context of ageing.

The article starts with a brief overview of existing theories on wellbeing and meaning in life, and explains why the authors think a new theory on meaning in life is necessary to better understand the variety of experiences of it in concrete life narratives. After outlining the essentials of Derkx $(2011,2013,2015)$ theory about meaning in life, we explore if and how the needs for meaning presented are taking shape in the daily life 
of the two older men. In the final part of the article, we discuss how the analysis of the cases may further refine and clarify the theory.

\section{Meaning in life}

What does it mean to live a good life? This ancient question was already addressed by founders of world religions and by playwrights and philosophers such as Sophocles and Aristotle. Although "the meaning of life" suggests a more objective, transcendent meaning ascribed to human life as a whole, "meaning in life", the term we focus on in this article, refers to subjective individual experiences. In modern philosophy, this theme is mostly studied in terms of "the good life" or "human flourishing", and in modern social science (including psychology) this is studied in terms of "well-being" and "quality of life". Well-being and quality of life seem general enough to include meaning in life. On closer examination, however, dominant definitions of well-being and quality of life (Diener et al. 2009; Ryff 2014; WHOQOL Group 1998) turn out to largely ignore important dimensions of meaning (which we will indicate below).

Publications on well-being and quality of life far outnumber publications on the related but different topics of meaning in life. Yet, since Frankl's publications on meaning in life (Frankl 2006, 1st ed. 1946), research on this subject has slowly but unmistakably increased. A selection of important books includes contributions from philosophy (Klemke \& Cahn 2008; May 2015; Wolf 2010), psychology (Baumeister 1991; Coleman et al. 2015; Hicks \& Routledge 2013; Wong 2012), history (Cole 1992), cultural anthropology (Mathews 1996), sociology (Inglis 2014) and also from interdisciplinary perspectives (Alma \& Smaling 2010; Edmondson 2015). These publications show that there is scant agreement on which theory of a meaningful life is the best starting point for further research. Despite the increased theoretical and empirical attention, many observers have noted "that the field still suffers from definitional ambiguity and simplified approaches that neglect the complexity and conceptual range of meaning in life as a construct" (Martela \& Steger 2016: 531). While Martela and Steger (2016) argue that meaning in life is most often understood in three different meanings (coherence, purpose and significance) and that suggested additional dimensions (in particular affective components such 
International Journal of Ageing and Later Life

as excitement [Morgan \& Farsides 2009]) should be regarded as potential sources of meaning rather than elements of the concept itself, we feel that the focus on lived experience of meaning is served by a theory that offers a differentiated view of the psychological, social, existential and moral needs that have to be fulfilled for a meaningful life.

After careful studying of a variety of social, psychological and philosophical sources, Derkx $(2011,2013,2015)$ proposes a model that encompasses seven such needs. Derkx uses meaning as a broad concept, which may encompass both active and passive modes of being, such as giving meaning to one's life, finding meaning in one's life or experiencing one's life as meaningful. The origin of this theory of meaning can be found in the work of social psychologist Baumeister (1991), who suggested four needs that should be satisfied to experience life as meaningful. Baumeister's four needs for meaning, which Derkx integrates in his own theory, are purpose, moral worth, self-worth and (efficacy or) perceived control. Baumeister's theory has a certain one-sidedness in its emphasis on individual agency and its neglect of communion (Bakan 1966; McAdams 1993; Smaling \& Alma 2010). Derkx (2011) therefore adds a need for connectedness, understood as being connected to other people, or to something other than oneself. Derkx has also been convinced that a need for coherence (or comprehensibility) has to be added (Heintzelman et al. 2013; Martela \& Steger 2016; Mooren 1998; Van Praag 1982). Finally, Derkx agrees with Morgan and Farsides, who have persuasively argued that a need for excitement is part of the overall need for meaning (Morgan \& Farsides 2009; see also Derkx 2015; Frankl 2006: 106-107; Melton \& Schulenberg 2007). Taken together, the need for moral worth, the need for connectedness and the need for excitement constitute the overarching need for something that may be called transcendence: the experience of being connected to a larger whole, of transcending one's own private interest and of transcending the context of the usual and the well known (Derkx 2013, 2015; Smaling \& Alma 2010).

Derkx' seven components or dimensions of meaning together sketch the conditions thought to be fulfilled when people experience their lives as meaningful. We will now discuss these components in turn.

- Purpose: to have a purpose in life means that someone is able to connect his or her current activities to a valued future state or aspired perspective. This purpose may be an external goal that one strives for, 
such as getting a certain job. Purpose, however, may also take shape as an experience of inner fulfilment, caused by the satisfaction that comes with having developed one's talents, for instance.

- Moral worth: to experience moral worth means one is able to evaluate one's own actions and way of living as morally justified or positively valued. People experience moral worth if they can be reasonably sure that their choices and actions are not morally blameworthy, but are in fact legitimate.

- Self-worth: a feeling of self-worth, including self-respect and selfacceptance, refers to a positive evaluation of oneself. This self-worth is often attained by way of comparison with others, and crucially depends on being socially recognised. Cultural traditions and social hierarchy play a large part in the development of self-worth. Selfworth both pertains to the value of who one is, and to the value of what one does. Furthermore, self-worth can be based on a positive evaluation of one's individual achievements, as well as derived from one's membership of a particular social group that contrasts favourably with other groups.

- Control: (perceived) control pertains to the need to believe that one's life is - to some extent - within one's own control. People need to feel that they are in charge of their lives, that things do not just happen to them. Even if objectively speaking, they know that circumstances largely escape their control, to experience meaning people still need to have the feeling that they are competent agents whose choices and actions actually matter. This sense of competence can not only be achieved by "real" control, but also by what is called interpretive control: if one can understand what happens, this insight generates a sense of competence and a change in how the event is experienced, even if the actual circumstances are not changed (Baumeister 1991: 42).

- Coherence (or comprehensibility): this component refers to the need for a coherent understanding of the reality in which one lives. This reality needs to be (to some extent) intelligible and well ordered to perceive life as meaningful because chaos and fragmentation cause distress and a disruption of meaning. The creation and maintenance of a coherent life narrative for oneself, which safeguards a stable sense of identity and of continuity (McAdams 1993), can satisfy this need. In a sense, the need for coherence can be seen as an element 
International Journal of Ageing and Later Life

of meaning overarching the others. Coherence is conditional for arriving at the interpretive control that was discussed above.

- The need for excitement, also meant to include wonder or curiosity, describes the importance of elements in our lives that breach the dullness, monotony and boredom of our routines, that spark our curiosity and that make life interesting for us. Excitement is the emotional response to things in our lives that have the power to motivate us to act in a certain direction. Importantly, excitement need not necessarily be caused by positive emotions; anger, resentment or fear can also cause excitement, and set things into motion that ultimately contributes to experiencing meaning in life; imagine political activists fighting injustice. Excitement, however, can also express itself in less activist manners; think, for instance, of an aesthetic experience of wonder or awe when one is immersed in nature or art.

- Connectedness: being connected to other people, or to something other than oneself, refers to having fulfilling contacts, and to feeling closeness or communion with others or "the other" in a broad sense. Smaling and Alma (2010) emphasise that in order for the need of connectedness to be fulfilled satisfactorily, it is important that we experience the other as fundamentally different from ourselves. Only then can we realise the experience of love, connection and surrender to someone else that is quintessential for connectedness. Yet, the need for connectedness need not be restricted to our personal relationships with other people; connectedness can also be expressed in citizenship or in efforts to realise a better, more humane society (Smaling \& Alma 2010). Moreover, connectedness can also be felt with an impersonal Other, with God, with nature or with a positively valued transcendent reality (Derkx 2013). The need for connectedness underscores the broader social embedding of human existence and emphasises how vital it is for the experience of meaning that our connections to others or "the other" have a positive quality.

These seven dimensions of meaning facilitate an important reflection on what makes life meaningful. Derkx (2013) agrees with Baumeister that the number of components is "somewhat arbitrary and irrelevant. What 
matters is the total conceptual space that they cover. (...) The important thing (...) is the totality, not the number of distinctions within it" (Baumeister 1991: 32).

As mentioned above, the social science concepts of "well-being" and "quality of life" differ from the concept of "meaning in life". Of the seven meaning dimensions just discussed, coherence and especially moral worth represent most of the difference. The seven components of meaning are intended to be exhaustive: if all are present to a sufficient degree, a person's life is expected to be meaningful. In contrast, if the seven needs for meaning are not fulfilled, the person involved will expectedly try to adapt their behaviour, interpret life differently, and avoid the threat of meaninglessness. Importantly, Derkx (2013) notes that the components of meaning are not mutually exclusive and can show overlap. Also, particular sources of experienced meaning (such as work or parenthood) may contribute to several needs at the same time.

\section{Methods}

In our aim to elaborate the theoretical components of meaning in life, we selected two single cases and analysed the interviews of Mr. Jansen and Mr. Pietersen (both aliases to ensure anonymity). Mr. Jansen was interviewed in the context of a project exploring ageing in a rural setting. Mr. Pietersen was interviewed in the context of a research project on social isolation of elderly persons. The interviews were carried out in 2012 and in 2015 and lasted more than 3 hours each.

We selected these cases for their rich narrative descriptions of lived experience, under the assumption that meanings tend to run through life narratives and can best be studied through them (McAdams 2009, 2011). Case studies provide insight into real-life people and narratives. In-depth study of single cases is essential for producing knowledge because case studies take the context into account. Flyvbjerg (2006: 237) argues that especially "good narratives" that typically approach the complexity and contradictions of real life are a substantial element of case study research. We underscore the importance of the context in our aim to explore lived experiences of meaning in life and selected these two cases because in our view they represent "good", deep and rich narratives, resulting from 
International Journal of Ageing and Later Life

both men's open-heartedness, clearness, contemplation and congruence in their way of reasoning and talking.

The knowledge from these two cases cannot be formally generalised, but the purely descriptive, phenomenological case studies can be of great value in the collective process of knowledge accumulation on meaning in life. According to Flyvbjerg (2008: 77), "the power of the good example is an important source of scientific development". The "generalisability" of the case studies is increased by selection of two critical cases: cases that are rich in information and cases that have strategic importance in relation to the general problem. Thus they can produce deeper insight into the problem that is central in this study (Flyvbjerg 2008: 78). The two cases are also interesting because similarities on various dimensions (e.g. both protagonists are born in 1927, both are male, white and widowed) and differences on some other dimensions (e.g. rural/urban and religious/ non-religious) shape the context of their narratives and can be expected to impact their experiences of ageing and meaning.

For this article, all four authors analysed both verbatim-transcribed narratives independently. We used Derkx' seven dimensions, as well as seven corresponding "lack of [dimension]" as codes. As researchers we were sensitised by Derkx' theory, but inevitably while coding the "bodies of knowledge" stemming from our different disciplines (philosophy, cultural anthropology, humanistic studies and social science) resonated in the background.

After completion of our separate analyses we compared and discussed our findings (researchers triangulation), thereby also paying attention to differences in interpretation that resulted from our interdisciplinary approach. During these discussions, we aimed to improve validity by [1] discussing our interpretations of the seven dimensions and [2] gaining agreement upon the codes we added to particular text segments.

In this article, we first present findings that are based upon agreements in our coding process to illustrate the meaning of the dimensions. Following the conventions of anthropological research, we describe our findings in this part of the article in an evocative, narrating style that aims to invite the reader "into the story". Eventually, we present a fine-tuning of the theoretical notions, based upon insights that occurred during our vivid discussions of contradictions and disagreements. 


\section{Two protagonists}

Mr. Jansen was born in 1927 and raised in an orthodox Protestant village (1800 inhabitants). His middle-class family consisted of four children three daughters and a son. He was one of the first teenagers of his village to receive a higher type of secondary education (HBS), but as his parents' only son he decided not to continue further studies and joined his father's business in textile, carpets, curtains and furniture. After marriage in 1954, he and his wife lived next to business and parents (in law) as an extended family. They had three daughters and two sons. In 1991, the first son took over business and the couple moved $1 \mathrm{~km}$ from Mr. Jansen's birth-house. In 2009, his youngest daughter and her family moved to this same house to live in an intergenerational setting. In 2013, Mr. Jansen's wife passed away. Mr. Jansen still supports his son in business by performing administrative tasks. He is an active church member and participates in the competition of a chess club on a weekly basis. Mr. Jansen evaluates himself as a valued person in his village and church community. He has an active social life with visitors several times a week and meets his children (and/ or grandchildren) on a daily basis. Mr. Jansen was interviewed when he was 86 years old.

Mr. Pietersen was also born in 1927, and when he was interviewed he was 84 and lived in Rotterdam, the second largest city of the Netherlands (635,000 inhabitants). He had no brothers and sisters, and describes himself as non-religious, although he prays in times of distress. He also completed a higher type of secondary education (HBS). Later, he attended the Academy of Arts because he had always had an artistic interest. His professional career included work in a variety of contexts, such as being art director at a large advertising company and working as a veterinary radiology technician. Mr. Pietersen's first marriage was unsatisfactory and ended in divorce. For 12 years he had a happy second marriage, but his second wife died of cancer in 1992, a loss he grieved over deeply for many years. He had no children and seldom saw his only remaining relative, a cousin. Ten years after the death of his second wife, he undertook several attempts to meet new women. One attempt seemed initially successful, until she suddenly died of lung cancer. Two acquaintances arranged for him to move from a town where he had lived and worked for years to a care home in Rotterdam, his city of origin. 
International Journal of Ageing and Later Life

He regretted this move and felt alone and not connected. At the time of the interview, he seriously thought of actively ending his own life.

\section{Empirical exploration of the seven components of meaning}

We confronted the seven components of meaning in life presented above with the transcribed interviews of both protagonists. In this section, we present our findings following the order of the components of meaning as we have elucidated them above.

\section{Purpose}

Derkx differentiates internal fulfilment from external goals. Purpose in the sense of internal fulfilment emerges in both narratives as related to past employment, and sharing reminiscences in this regard appears a meaning-instigating activity. So the experience of purpose in life can refer to a direction towards the future one has had in the past. Reactivating memories of purposeful activities from the past during the interview seemed helpful for re-experiencing a sense of meaning in the present. Mr. Jansen mentions:

I had my business and visited my regular customers, and of course this was to earn my income, but it came with a social component as well [...] I even helped children with homework, especially mathematics was my specialism, and then I stayed a little longer, like an hour, to help a child or people who botched, so to speak. Helping other people comes with joy. And if they share their gratefulness...these are the sparkles of life. (Quotes are translated from Dutch by the authors)

The nature of this inner fulfilment appears to relate to connectedness and moral worth.

Mr. Pietersen reflects in a different way upon his employment. He emphasises how his work distracted him from mourning after his wife passed away. His work became a tool to move on in grief-stricken periods. However, it also appears as a more profound meaning provider when he elaborates upon his status as higher educated artist, manager of an advertising agency, self-taught radiologist and computer specialist. Throughout the interview he proudly presents himself as an intelligent and intellectual multi-tasker and in this sense his employment not only provided purpose and self-worth - in the past, but it still does in sharing his story. 
Another source of purpose that emerges from the narratives is religiosity. While Mr. Pietersen lacks affinity with religion, Mr. Jansen practices Christianity and he construes his religion as an asset. Mr. Jansen believes that Christians are obliged to care for other people, society and the world. In the evening of his life, and due to heart failure and decreased mobility, he experiences fewer possibilities to do so. Nevertheless, he aims to satisfy the purpose of caring for other people with actions that are still feasible, such as helping his son with preparing accounts and bills, and showing interest in his neighbours and fellow-villagers. The Christian obligation to care not only provides purpose, but, of course, also relates to moral worth.

Involvement in our research, by putting their life narratives into words, brought purpose in itself. As Mr. Jansen stated: "I am content that I can help you with your work". He appeared visibly pleased by a visit of - in his eyes - highly regarded researchers who find him worthwhile to listen to for several hours and he explicitly expressed his interest in reading the results. In that sense, his involvement in this research gives him a sense of purpose.

Mr. Pietersen appreciated the time and attention of the researcher in a different way. In the past decades he had lost important loved ones and his health dropped as well. While living in a care home with - in his words - "stupid, intensely bourgeois grannies", he does not feel connected with people. But the visit of a researcher, and also a social worker, stimulates a sense of meaning. He states: "Last month, I wonder, what is going on? More people are coming to me and show interest in $\mathrm{me}^{\prime \prime}$.

While talking to the researcher he describes why he divorced his first wife in middle age and how he met his second wife soon afterwards. After the loss of his second wife (1992) and also the loss of his third partner (10 years later) he felt gloomy. He shared his concerns with his doctor, who reacted:

You are not depressed, but you are simply awfully unhappy. I can help depressed people, but I cannot help unhappy people. You should get yourself a new partner and start dating.

With this advice in mind (it was offered a couple of months before the interview took place), Mr. Pietersen starts dating. Actually, he thinks 
International Journal of Ageing and Later Life

his doctor gave him a ridiculous advice, but he decides to give it a try. He posts his profile on a dating site.

I added my age, 84, and a photo of this old face, and even on the first day I received dozens of emails [...] all from divorced women in their fifties, sending messages to an 84 year old man.

He somehow appears animated about the results, but it also confirms his initial opinion about the doctor's advice and he concludes that this category of women is not what he is looking for. They do not have enough interests in common with him and he discontinues dating. Nevertheless, the dating project gives him a purpose and generates excitement; it even touches upon his sense of self-worth. The sense of purpose as effect of this initiative is rather practical; it offers him an activity to fill some time, but the positive effects are merely temporary. His long-term aim is not fulfilled because Mr. Pietersen is not searching for superficial attention but deeply longing for a sustainable relationship with a suitable partner. A partner is crucial for him to experience a sense of meaning:

[...] someone I can talk to, having a normal conversation, drinking a glass of wine in the evening with some cheese, watching TV, listening to music, whatever. That is what I like to do with a partner. Being together, that is what everybody wants.

Mr. Pietersen aims to find himself a new partner "to do things", but even more he longs to share his life with a like-minded person. Neither the "grannies" in the home nor the respondents on the dating-site meet this end.

Although purpose, in principle, implies a future-directed orientation, the narratives of our protagonists suggest that achieved, experienced and remembered purposes from the past seem perfectly capable to provide meaning in the present. Perhaps, with older people, in a situation where, objectively speaking, a long personal future is no longer to be expected, the need for purpose may thus also be satisfied by fondly looking back on what was achieved and experienced in life much earlier (Erikson 1997). This may partially counteract the loss of purpose which is often found in older persons (Irving et al. 2017). 
Some purposes provide temporary fulfilment; other purposes have a more profound and sustainable basis. The analysis revealed that themes such as religiosity, altruism, societal involvement and personal relationships are important sources of purpose. These themes are also related to connectedness, self-worth and excitement, which will be elaborated below.

\section{Moral worth}

During World War II, both protagonists were 13-18 years old and although they lived in very different settings, these years had major impact on both of them. Mr. Pietersen lived in Rotterdam, a city whose inhabitants suffered severe bombing raids and starvation. Mr. Pietersen's father was a member of the illegal resistance. As a teenager Mr. Pietersen played as musician during liberation celebrations. He fondly describes his performances for the Allied Forces, and he uses a nickname with a strongly negative connotation for the German oppressors ("moffen").

Mr. Jansen lived through the war in a rural context with farms and enough food. He describes his father-in-law's detention and eventual death in concentration camp Buchenwald, due to betrayal by people "on the wrong side". The war appears a dividing line in both narratives: it separates their narrative in a "before and after". Both protagonists spontaneously share these war memories and in content as well as in the words they choose they justify their moral stance: they were "on the right side". Moral worth in past experiences in this sense appears in both narratives as meaning provider.

Moral worth, as a present-day qualification of his life, appeared merely marginally in Mr. Pietersen's narrative. "I have never hurt people, never lied to people and I always worked hard", he utters as a complaint regarding his current living conditions in an old people's home. He feels he deserves a better life, in better circumstances, "I do not want this life anymore. I can jump in front of a train or from a roof, but that will hurt other people" and that does not comply with his moral values. Mr. Pietersen shares moral worth here, but it is questionable whether the expressed concern for other people in this context contributes to his sense of meaning. 
International Journal of Ageing and Later Life

While present-day moral worth does not appear prominently in Mr. Pietersen's narrative, it is vibrating throughout Mr. Jansen's narrative. Mr. Jansen emphasises responsibilities to care for each other, for society and for the environment. When asked about what is the core of his view of life, he stated:

To make a contribution to society and to life. Yes. I think one of the Christian commands is to keep contributing, in whatever way, to people, to society ... That makes life meaningful.

He underscores his moral values with examples from the lives of his parents, his children and particularly his own life. For him people have responsibility for each other, for instance, towards their spouse and towards children. Also in a broader sense, he expresses his intent to keep showing interest in other village community members:

I usually force myself to not always sit next to the same and like-minded people, but also aspire to relate to people who are not religious or with different political interests. Showing sincere interest in each other is of paramount importance.

He aims to live up to these moral values and to fulfil an exemplary role for others. To his own opinion, he succeeds quite well in doing so and this conclusion bridges moral worth to self-worth.

\section{Self-worth}

Both Mr. Jansen and Mr. Pietersen experience an age-related increase of dependence on other people. Either receiving care from formal (Mr. Pietersen) or informal (Mr. Jansen) caregivers, both are reliant on help for daily needs. Loss of health and strength - inevitably related to the process of ageing - comes with a risk for an imbalance in giving and receiving.

Mr. Jansen is living in his community, cared for by his children. This offers him the opportunity not only to receive care, but to give care as well in the sense of attention, involvement and help. His value as pater familias is confirmed on a daily basis. In addition, he is receiving care from his children, who depended on his own care in their youth. This position noticeably influences his self-worth, although he admits that growing dependent is sometimes challenging: 
Asking ... Asking ... "Do you want to do this for me?" And they do it with pleasure, they do it with love. But the asking in itself ... that is difficult. ... The asking and not being able to do it yourself any longer.

Nevertheless, Mr. Jansen shows a strong sense of self-worth. His valued position in his community and family gives him much satisfaction. This sense of self-worth, however, is not only regarded as a personal achievement. Mr. Jansen repeatedly utters a feeling of what he calls "gratitude" ("dankbaarheid" in Dutch). When reflecting on what has been most important in his life, he states:

When I look back ... I say, I have had a beautiful life, a good life, ... a blessed life. ... When I compare myself ... when I see what other people sometimes have to endure ... we have not lost a child, in a manner of speaking. ... That sadness did not happen to us, our five children were born in good health and live. So if you measure yourself by what you did not have to endure ... you only become glad and grateful for that.

He repeatedly expresses that he feels privileged and blessed compared with other people in terms of safety, security, housing situation and his marriage of almost 60 years. This social comparison apparently strongly contributes to his positive evaluation of his life.

In contrast, Mr. Pietersen has lost all his loved ones. He receives help and care from professionals in a setting where "not disturbing care-givers" is a virtue. His dependence undermines his self-worth. Mr. Pietersen is less in a position to give, whereas Mr. Jansen has given already in the past and is still in a position to give love, attention and even presents (money) to his significant relations. The reciprocity in his relationships enables Mr. Jansen to perceive his existence as an asset, whereas Mr. Pietersen experiences his life as a burden, for others as well as for himself.

Nevertheless, Mr. Pietersen also reveals elements of self-worth in his narrative. He explains, for instance, that his doctor approached him for a presentation about his life history in a health centre. He is noticeably pleased by this request, but not surprised. Our research interest in his life narrative also appears as a self-evident matter. During the interview, he several times elaborates on his - in his eyes - above average talents and intelligence. His self-worth appears to have its deeper foundation in earlier stages of his life: "I have had a very happy childhood and my parents 
International Journal of Ageing and Later Life

allowed me to study. This was exceptional in those days". But his original sense of self-worth is challenged by his negative perception of his circumstances in old age. He cites the words of his doctor who told him: "I explain something to you: 'actually you are finished, you have passed the expiration date'". Several times he expresses his disgust over the decline of aged people and he openly states: "I have advanced plans to end my life. I have everything ready in my house, including a bottle of helium. My doctor is informed and my friends as well".

We observed that both men originally have a strong foundation of selfworth. For Mr. Pietersen however, his self-worth has become ambiguous due to his age-associated lack of mobility and feelings of loneliness. Mr. Jansen does not express such ambiguity. His value is underscored by his social connections on a daily basis, and this embedding appears to secure his self-worth. This confirms the profound importance of reciprocity for sustainable relations with others (Komter 2007; Mauss 1966). It is also noteworthy that for both protagonists, self-worth seems to be crucially related to autonomous agency (Benson 1994), which suggests that there is an important connection between self-worth and control.

\section{Control}

People need to feel that they are in charge of their lives and that things do not just happen to them. As mentioned above, Mr. Pietersen has collected the means and equipment to end his life, a radical solution that expresses taking control over his life and death. Interestingly, at this point in his narrative he exhibits a striking sense of humour that seems to help him deal with the tragedy of his situation. To commit suicide by suffocation with helium gas, as he plans, he needs a plastic bag to pull over his head. For this he has ordered some oven bags. He finds the letter accompanying his order, wishing him "much cooking pleasure", hilarious, and is keen to share this joke with the interviewer. His black humour seems to serve a function in maintaining some sense of control here, albeit in a rather cynical way.

However, in a far more frequent sense Mr. Pietersen's narrative shows lack of control because he failed to prevent a negative turn in his circumstances. He explains, "I was trapped, I was misled, I was deported". He uses words with a severe negative connotation while explaining how he moved from his home in a small city to a care home in Rotterdam. 
Two acquaintances convinced him, after his wife's death. He felt deep grief about his loss and explains:

I surrendered [myself] to these two ladies who were intelligent and younger than I. I was already a little bit an old man, a bit slumbering, a bit depressed, a bit in a dip, so [I thought] they will know [what is best]...I don't think I had feelings at all, I was numbed, probably.

The consequences of this loss of control are bitter; due to this move he lost his home and his books: "...these were all thrown away, that was a disaster and caused that I was even further astray".

Mr. Jansen copes with finitude of his life in a different way. Although the process of dying worries him, he believes in an eternal life after death, and in that sense death is under control. Mr. Jansen, however, has to deal with a different lack of control: as a father he feels he failed to transmit his religious beliefs to all of his children.

I regret that and it comes with sorrow...nowadays I believe in heaven but I doubt there is a hell... Before, the people in my church believed that non-Christians would go to hell, but I do not believe that anymore because God is love and goodness.

In his eyes some of his children went astray in a spiritual sense and he failed to prevent it. But it is interesting to note that he gradually lost his belief in hell and with this adaptation in his religious convictions his apostate children are saved from eternal misery in his perception. $\mathrm{He}$ may be unconscious of this himself, but we perceive this manoeuvre as a form of agency in controlling an unbearable future perspective for his children and thus for himself.

\section{Coherence}

Coherence or comprehensibility proved to be hard to illustrate with a specific section or quotes. However, both narratives give a general impression of coherence throughout the interviews. Mr. Pietersen, for instance, starts the interview with a description of his personality.

I am not very diplomatic, I am very straight and to the point. I call this "honest", but people sometimes think I am not tactful, and unkind. I am not always a kind person. 
International Journal of Ageing and Later Life

Mr. Pietersen shows awareness of his personality and this kind of comprehension seems related to a more general coherence in his self-understanding. Mr. Pietersen exhibits a strong and somewhat dominant personality when he talks about himself in his past life. He sketches an exciting life of an intelligent man, brimming over with creative initiatives. The way he represents himself in his earlier life to the interviewer is with a consistent amount of self-worth, control, purpose, excitement, moral justification and, last but not least, social connectedness.

His present life shows a break with this image however. This break is related to the loss of his beloved second wife, and his subsequent somewhat enforced move to the nursing home. This loss of control is not in line with the control he used to have in life. With his loss of social connectedness and social embedding, he eventually loses his lust for life, his sense of meaning. He understands what happened to him, but he does not really understand why he let it happen.

\footnotetext{
After my wife had died and I was alone, I have been very unhappy. I still do not comprehend why I have been alone so long, why I did not look for yet another partner. I do not know. Have I been mourning so long or am I a silly fool?
}

Mr. Jansen also endured the life-changing event of losing his beloved wife. However, his meaning framework has remained more or less intact. Although he mourns the loss of his wife, his self-worth, control, purpose, moral justification and social embedding are not permanently affected. Also, the way he perceives his personality as a respected, kind and religious person is steady and coherent throughout the narrative. His religious convictions, although in the course of time slightly evolved towards less orthodox views, have offered him direction and perspective throughout his life. This illustrates how religion can not only provide purpose and moral worth, but also constancy, continuity and coherence.

It may be suggested then that breaches in the coherence of one's life narrative, due to different types of loss, need not necessarily disrupt meaning in the long run, as long as a supporting environment is present to facilitate restoring coherence. For Mr. Jansen, this is clearly the case. 
For Mr. Pietersen, however, such support is lacking, and as a result he does not manage to integrate his losses in his life narrative in a coherent way. Moreover, this experienced lack of coherence is intensified because he does not comprehend his inability to deal with it more effectively. This, of course, also relates to lack of control.

\section{Excitement}

Both men show a lot of excitement when they share their professional past with the interviewers. In their work, they felt respected for their intellect, their talents and abilities, and their social status. This form of excitement seems related to self-worth and - through respect and status - also to social connectedness. Sharing these memories with the interviewer causes excitement retroactively. This excitement is not the superficial kind of enthusiasm, but related to a deep passion. Such passion is not only expressed by both men regarding their past professional life, but also with regard to meaningful relationships with (one of) their wives and for Mr. Jansen also with his children and grandchildren.

Although excitement often relates to pleasant emotions, it can be related to negative feelings as well. Mr. Pietersen expresses a lot of frustration and anger and although such feelings can lead to actions that inspire meaning, for Mr. Pietersen this is not the case. His negative emotions are one of the reasons that he considers to step out of his life. Consequently, we observed that while excitement in the form of high expectation, enthusiasm, wonder, curiosity, and even anger and fear can contribute to meaning indeed, when it comes in the form of heavy disappointment, anger or fear, it may be more likely to produce a decrease in or a lack of meaning.

\section{Connectedness}

In the narratives of both protagonists, connectedness emerges as a profoundly important dimension.

Mr. Pietersen is as explicit as can be about the importance of social connectedness: "Being together, that is the only thing of importance. The only thing. Nothing else". Mr. Jansen is very grateful for the strong social 
International Journal of Ageing and Later Life

embedding in his community that he enjoys. He explains how, during his wife's illness and after her death, their shared lifelong investment in a variety of social contacts proved very valuable:

I still get a lot of visits, because... my wife, she knew (...) that she was terminally ill... and... those where still three very beautiful months... that sounds a bit strange... (...) until the end, she laughed every day, she enjoyed life, she got a lot of visitors, a lot of phone calls, a lot of postcards and ehm... that was the fruit... of my wife's social side.

However, Derkx (2013) described connectedness not merely as a social dimension of meaning in life; it also stands for relatedness with something beyond connections with other persons and in this sense both men's narratives illustrate a significant difference. Mr. Jansen not only feels connected with human beings but also with his natural environment and the earth. His religion brings him a social (church) community in which he feels valued, but it also brings him a connection with a wider reality than just the social, human world. His religion brings him a future with hopeful perspectives:

Both my wife and I believed that we will have a life after this life, in impeccable harmony, entire peace and justice, where a lamb can live with a lion. It is difficult to comprehend, but believing is...is a matter of trust.

It is striking that even in this view of life after death, of heaven, social connectedness is paramount: living together in harmony, peace and justice.

Mr. Pietersen has never joined a religious organisation or a church. He says: "I am not a believer, absolutely not, but I pray each day. ... I pray to God". His praying to God comes down to asking favours, for example, to be able to walk better. Mr. Pietersen is capable of experiencing meaning in the here and now, as long as he is surrounded by at least one beloved person. Although he prays, God obviously does not meet his need for companionship. After the loss of his beloved wife, he loses his zest for life. Even though he is in a nursing home, with a lot of dwellers and caregivers around him, these people do not fulfil his need. Superficial social contacts are inadequate. A significant personal relationship with a woman is a prerequisite for Mr. Pietersen.

We observed that for both protagonists, social connectedness seems to be intertwined with and even conditional for other needs for meaning. 
Their experiences of purpose, moral worth, self-worth and coherence, for instance, all seemed related to and even dependent on the value of their relationships with other people. This suggests a possible constitutive function of connectedness relative to other meaning components that merits further investigation.

\section{Discussion: Beyond the seven components?}

In the preceding section, we have shown how each of the seven components of meaning presented in the beginning of this article can be used to analyse elements of meaning (or lack thereof) in life narratives. In our methodical approach of discussing our interview coding through researcher triangulation, three themes in particular led to debates about a potential refinement or further deepening of Derkx' theory $(2011,2013,2015)$ : gratitude, social comparison and humour. We will discuss these themes and their possible relation to meaning below, and provide an initial attempt to interpret them, although further research is clearly needed here.

As discussed in the section on self-worth above, gratitude is an important theme in Mr. Jansen's narrative. His feeling that he is "privileged on all sides" is clearly highly conducive for his experience of life as meaningful. Mr. Jansen's narrative in our view suggests an interpretation in which gratitude is not perceived as a fleeting emotional state or a reaction to a particular instance of benevolence, but as a virtue, a more enduring disposition or character trait. Watkins and McCurrach (2017) define "trait gratitude" in the following way: "if an individual is high in trait gratitude, then they should experience gratitude more easily and more frequently than someone who is not a grateful person" (p. 4). Empirical studies indicate that trait gratitude is positively associated with happiness, as well as with religiosity and spirituality (Watkins \& McCurrach 2017).

We think that a relationship between gratitude and meaning in life is plausible; however, we think it is unnecessary to add gratitude as a separate defining component of meaning in Derkx (2013) theory. Mr. Jansen's gratitude can be interpreted as a form of connectedness that is intertwined with feelings of transcendence and self-worth. He feels connected to and part of a larger whole, which he experiences as beautiful, good and "benevolent". His "joyful" Christian faith does not emphasise human sinfulness, but focuses instead on life as a gift that merits gratitude, not 
International Journal of Ageing and Later Life

as a terrible ordeal to endure. Mr. Jansen's gratitude-linked sense of selfworth is not only a personal achievement but also a part of a positive view of the world, which one might call "world-worth" or "world-acceptance". In contrast, Mr. Pietersen's narrative lacks any sign of gratitude.

It struck us that in both narratives, social comparison, either with others or with one's own situation in the past, played an important role in relation to experiences of meaning. Mr. Jansen frequently compares his own situation with that of others in a favourable way. This is in accordance with research that perceives social comparison as an important aspect of social connectedness (Weiss 1973). Mr. Pietersen, on the contrary, contrasts his present painful lack of personal contact with like-minded people with his happy youth and second marriage. This confirms Gerber's observation, referring to research by Ferring and Hoffmann (2007), that "in older age, temporal comparison (comparing to past selves) becomes increasingly important" (2017: 5).

For older people, social comparison is shown to play a particularly important role in their evaluation of their own (health) situation (Von Faber et al. 2001: 2698). This shows that experiencing well-being or good health is not something evaluated in absolute terms. Mostly, it is relative in comparison with others. We suggest that something similar may apply to meaning. Baumeister (1991: 44) already pointed out that someone's sense of (positive or negative) self-worth is, to a large extent, dependent on comparisons with and evaluations by significant others. The stories of our protagonists confirm that inter-individual comparison can be important for evaluations of the meaningfulness (or meaninglessness) of one's life. We suggest that applying social comparison theory (Gerber 2017; Gerber et al. 2018) to issues of meaning in life could generate valuable new research angles.

Our analysis, particularly of Mr. Pietersen's narrative, brought us the insight that humour may also play a role in experiencing life as more meaningful or less meaningful. Joubert (2015: Note 1) is of the opinion that irony is a weapon ("it attacks") and humour is a shield ("it protects"). Humour is a defensive mechanism and can, for example, protect against or help to deal with meaninglessness. This may be prevalent in the case of Mr. Pietersen. He uses black humour as a shield against painful situations. For example, he cherishes the incongruous characterisation of his first unsuccessful marriage as a business company, referring to himself and 
his wife as "the Pietersen Company" (one of the most plausible theories of humour is the incongruity theory; see Carroll 2005; Morreall 2016). Black humour as a shield can be understood as a kind of control, as we illustrated with regard to his jokes about the plastic oven bag involved in his plans to suffocate himself with helium gas. Because the objective situation does not change by it, here humour is a kind of interpretive control. This suggests humour does not have to be added as another dimension of meaning to the seven already distinguished. In Mr. Jansen's narrative, humour was not explicitly present, perhaps because its function as a shield against painful situations is not so urgently needed in his situation. Of course, humour could play a role for him as well in experiencing life as meaningful. In any case, the role of humour as related to meaning in life is an interesting angle for further research.

\section{Conclusion}

We conclude that Derkx' theory of meaning $(2011,2013,2015)$, when applied to life narratives, provides a helpful framework in analysing what causes people to experience their life as meaningful or not. The following points should be taken into account in further theoretical and empirical explorations.

We found that the theoretically distinct components of meaning were intertwined in the studied narratives in several ways. Quite often a fragment in an interview could be linked to more than one component of meaning, and all of these ascriptions seemed to have an element of truth. In discussion between the authors it was regularly agreed that one component was most important in the particular context of a (larger) fragment. Alternatively, we also encountered instances where components of meaning seemed to be in tension (as we saw regarding control and connectedness, or regarding self-worth and (lack of) control). A balance between needs associated with agency, such as control and self-worth, and needs associated with communion, such as connectedness and moral worth, seems crucial for the experience of meaning (Bakan 1966; McAdams 1993). Consequently, further research is needed to explore the relations and possible tensions between the different components of meaning. This should include questions about whether components can compensate for each other (i.e. does high fulfilment of the need for connectedness make a sense of purpose less or not necessary?) and whether 
International Journal of Ageing and Later Life

a certain balance between some components (e.g. self-worth and connectedness) is advantageous or even indispensable (Hornsey \& Jetten 2004).

Both narratives suggest clearly that the experience of (a lack of) meaning in life is not a momentary thing. Evaluating the degree of meaningfulness of their lives at a particular moment, our two protagonists take a life-course perspective that connects their past, present and anticipated future and is highly influenced by the sociocultural setting in which life takes place. The life-course perspective is not only a relatively recent fashion in research (Steger et al. [2013: 12] call it a "new promise" for meaning in life research), but it also seems a rather natural attitude of (at least) older people. Following from this, we highly recommend to always take a life-course perspective in studying meaning in later life. Such perspective should also include the temporal dimensions of specific meaning components, which seem of special relevance from the perspective of ageing (e.g. can experienced purpose in the past generate meaning in the present?).

In our discussions about the components of meaning in life as they appeared in the narratives of both protagonists, we concluded that connectedness (especially connectedness with other persons) seems to be a component of fundamental, constitutive importance. On the one hand, this should not surprise us as it may be explained by the intrinsic social nature and social embedding of individuals that are characteristics of the human condition. This implies that connectedness could be conditional to experience the other six dimensions of meaning. On the other hand, we observed that connections with others are not necessarily positive and that the quality of social relations really matters. Social relations with others may be characterised by neglect and indifference. In addition, connectedness can conflict with other meaning needs, such as control, where we found some tensions, particularly regarding the acceptance of becoming more dependent on one's social surroundings for help and support. The position of connectedness in the theory about meaning in life deserves a more thorough exploration.

\section{Acknowledgements}

The origin of this article was a symposium at the $45^{\text {th }}$ Annual Conference of the British Society of Gerontology at the University of Stirling, Scotland, 
UK, 6 July 2016. Part of it was also presented in a symposium at the $21^{\text {st }}$ International Association of Gerontology and Geriatrics (IAGG) World Congress, San Francisco, California, USA, 26 July 2017. We express our thanks to Dominique Verté and Daan Duppen, both from the Vrije Universiteit Brussel (VUB), Belgium, for participating in our symposia, to our colleagues Joachim Duyndam and Wander van der Vaart for long-standing cooperation in our meaning in life research, and to the two older men interviewed, who have to remain anonymous.

\section{Corresponding Author}

Pien Bos, University of Humanistic Studies, Kromme Nieuwegracht 29, PO Box 797, 3500 AT Utrecht, The Netherlands. Email: p.bos@uvh.nl

\section{References}

Alma, H. A. \& Smaling, A. (eds.) (2010). Waarvoor je leeft: Studies naar humanistische bronnen van zin [What You Live For: Inquiries into Humanistic Sources of Meaning]. Amsterdam: SWP.

Baars, J., Dannefer, D., Phillipson, C. \& Walker, A. (eds.) (2006). Aging, Globalization and Inequality: The New Critical Gerontology. Amityville, NY: Baywood.

Baars, J., Dohmen, J., Grenier, A. \& Phillipson, C. (eds.) (2013). Ageing, Meaning and Social Structure: Connecting Critical and Humanistic Gerontology. Bristol: Policy Press.

Bakan, D. (1966). The Duality of Human Existence: Isolation and Communion in Western Man. Boston, MA: Beacon Press.

Baumeister, R. F. (1991). Meanings of Life. New York, NY: Guilford Press.

Benson, P. (1994) Free agency and self-worth. Journal of Philosophy 91(12): 650-668.

Bovenberg, L., Van Ewijk, C. \& Westerhout, E. (eds.) (2012). The Future of Multi-Pillar Pensions. Cambridge, UK: Cambridge University Press.

Carroll, N. (2009). Humour. In J. Levinson (ed.), The Oxford Handbook of Aesthetics. Oxford: Oxford University Press. Available on www.oxfordhandbooks.com (Accessed: May 25, 2018).

Cole, T. R. (1992). The Journey of Life: A Cultural History of Aging in America. Cambridge, UK: Cambridge University Press. 
International Journal of Ageing and Later Life

Coleman, P. G., Ivani-Chalian, C. \& Robinson, M. (2015). Self and Meaning in the Lives of Older People: Case Studies over Twenty Years. Cambridge, UK: Cambridge University Press.

Derkx, P. (2011). Humanisme, zinvol leven en nooit meer 'ouder worden': een levensbeschouwelijke visie op ingrijpende biomedisch-technologische levensverlenging. [Humanism, Meaning in Life and 'Never Ageing Anymore': Reflections on Substantial Biomedical-Technological Life Extension, from a Worldview Perspective] Brussels: ASP, VUBPRESS.

Derkx, P. (2013). Humanism as a meaning frame. In A. B. Pinn (ed.), What Is Humanism and Why Does It Matter? (pp. 42-57). Durham: Acumen.

Derkx, P. (2015). The future of humanism. In A. Copson \& A. C. Grayling (eds.), The Wiley Blackwell Handbook of Humanism (pp. 426-439). Chichester, West Sussex, UK: Wiley Blackwell.

Derkx, P., Maas, A. \& Machielse, A. (eds.) (2011). Goed ouder worden [Ageing Well]. Amsterdam: SWP.

Diener, E., Scollon, C. N. \& Lucas, R. E. (2009). The evolving concept of subjective well-being: The multi-faceted nature of happiness. In E. Diener (ed.), Assessing Well-Being: The Collected Works of Ed Diener (pp. 67-100). Dordrecht: Springer.

Edmondson, R. (2015). Ageing, Insight and Wisdom: Meaning and Practice across the Lifecourse. Bristol: Policy Press.

Erikson, E. H. (1997). The Life Cycle Completed. Extended version with new chapters on the ninth stage of development by J. M. Erikson. New York, NY: Norton.

Ferring, D. \& Hoffmann, M. (2007). "Still the same and better off than others?": Social and temporal comparisons in old age. European Journal of Ageing 4: 23-34.

Flyvbjerg, B. (2006). Five misunderstandings about case-study research. Qualitative Inquiry 12(2): 219-245.

Flyvbjerg, B. (2008). Making Social Science Matter: Why Social Inquiry Fails and How It Can Succeed Again. Cambridge: Cambridge University Press.

Frankl, V E. (2006). Man's Search for Meaning (first published in German in 1946). Boston, MA: Beacon Press.

Gerber, J. P. (2017). Social comparison theory. In V. Zeigler Hill \& T. K. Shackelford (eds.), Encyclopedia of Personality and Individual Differences. Cham, Switzerland:Springer International. Available on https:/ / link.springer. 
com/referenceworkentry/10.1007\%2F978-3-319-28099-8_1182-1 (Accessed: July 5, 2018).

Gerber, J. P, Wheeler, L. \& Suls, J. (2018). A social comparison theory meta-analysis 60+ years on. Psychological Bulletin 144(2): 177-197.

Heintzelman, S. J., Trent, J. \& King, L. A. (2013). Encounters with objective coherence and the experience of meaning in life. Psychological Science 24(6): 991-998.

Hicks, J. \& Routledge, C. (eds.) (2013). The Experience of Meaning in Life: Classical Perspectives, Emerging Themes, and Controversies. Dordrecht: Springer.

Hornsey, M. J. \& Jetten, J. (2004). The individual within the group: Balancing the need to belong with the need to be different. Personality and Social Psychology Review 8(3): 248-264.

Hupkens, S., Machielse, A., Goumans, M. \& Derkx, P. (2018). Meaning in life of older persons. An integrative literature review. Nursing Ethics 25(8): 973-991.

Immergut, E. M., Anderson, K. M. \& Schulze, I. (2009). The Handbook of West European Pension Politics. Oxford University Press.

Inglis, T. (2014). Meanings of Life in Contemporary Ireland: Webs of Significance. New York, NY: Palgrave Macmillan.

Irving, J., Davis, S. \& Collier, A. (2017). Aging with purpose: Systematic search and review of literature pertaining to older adults and purpose. The International Journal of Aging and Human Development 85(4): 403-437.

Joubert, L. (2015). Humour and irony in Québec women's writing, 1970-2010: Taking the pulse of a resistance. In C. Sugars (ed.) The Oxford Handbook of Canadian Literature. New York, NY: Oxford University Press. Available on www.oxfordhandbooks.com (Accessed: May 26, 2018).

Kennedy, B. K., Berger, S. L., Brunet, A., Campisi, J., Cuervo, A. M., Epel, E. S., Franceschi, C., Lithgow, G. J., Morimoto, R. I., Pessin, J. E., Rando, T. A., Richardson, A., Schadt, E. E., Wyss-Coray, T. \& Sierra, F. (2014). Geroscience: Linking aging to chronic disease. Cell 159: 709-713.

Klemke, E. D. \& Cahn, S. M. (eds.) (2008). The Meaning of Life: A Reader. New York, NY: Oxford University Press.

Komter, A. (2007). Gifts and social relations: The mechanisms of reciprocity. International Sociology 22(1): 93-107. 
International Journal of Ageing and Later Life

Martela, F. \& Steger, M. F. (2016). The three meanings of meaning in life: Distinguishing coherence, purpose, and significance. The Journal of Positive Psychology 11(5): 531-545.

Mathews, G. (1996). What Makes Life Worth Living? How Japanese and Americans Make Sense of Their Worlds. Berkeley, CA: University of California Press.

Mauss, M. (1966). The Gift: Forms and Functions of Exchange in Archaic Societies. Translated by I. Cunnison. With an Introduction by E. E. Evans-Pritchard. London: Cohen and West. Originally published in French in 1923-24.

May, T. (2015). A Significant Life: Human Meaning in a Silent Universe. Chicago, IL: The University of Chicago Press.

McAdams, D. P. (1993). The Stories We Live By: Personal Myths and the Making of the Self. New York, NY: The Guilford Press.

McAdams, D. P. (2009). The moral personality. In D. Narvaez \& D. K. Lapsley (eds.), Personality, Identity, and Character: Explorations in Moral Psychology (pp. 11-29). Cambridge, UK: Cambridge University Press.

McAdams, D. P. (2011). Narrative identity. In S. J. Schwartz, K. Luyckx \& V. L. Vignoles (eds.), Handbook of Identity Theory and Research (pp. 99-115). New York: Springer.

Melton, A. M. A. \& Schulenberg, S. E. (2007). On the relationship between meaning in life and boredom proneness: Examining a logotherapy postulate. Psychological Reports 101: 1016-1022.

Mooren, J. H. (1998). Zingeving en cognitieve regulatie: een conceptueel model ten behoeve van onderzoek naar zingeving en levensbeschouwing [Meaning and cognitive regulation: a conceptual model for research on meaning in life and worldviews]. In J. Janssen, R. Van Uden \& H. Van Der Ven (eds.), Schering en inslag: opstellen over religie in de hedendaagse cultuur [Warp and Weft: Essays on Religion in Contemporary Culture] (pp. 193-206). Nijmegen: Katholiek Studiecentrum voor Geestelijke Volksgezondheid.

Morgan, J. \& Farsides, T. (2009). Measuring meaning in life. Journal of Happiness Studies 10(3): 197-214.

Morreall, J. (2016). Philosophy of humor. In E. N. Zalta (ed.), The Stanford Encyclopedia of Philosophy (Winter 2016 Edition). Available 
on https://plato.stanford.edu/archives/win2016/entries/humor/ (Accessed: May 31, 2018).

Olshansky, S. J., Perry, D., Miller, R. A. \& Butler, R. N. (2006). In pursuit of the longevity dividend: What should we be doing to prepare for the unprecedented aging of humanity? The Scientist 20(3): 28-36.

Reinhardt, U. E. (2003). Does the aging of the population really drive the demand for health care? Health Affairs 22(6): 27-39.

Ryff, C.D. (2014). Psychological well-being revisited: Advances in the science and practice of eudaimonia. Psychotherapy and Psychosomatics 83(1): 10-28.

Sierra, F., Hadley, E., Suzman, R. \& Hodes, R. (2009). Prospects for life span extension. Annual Review of Medicine 60: 457-469.

Smaling, A. \& Alma, H. A. (2010). Zingeving en levensbeschouwing: een conceptuele en thematische verkenning [Meaning in life and worldview: a conceptual and thematic exploration]. In H. A. Alma, \& A. Smaling, (eds.), (2010). Waarvoor je leeft: studies naar humanistische bronnen van zin [What You Live For: Inquiries into Humanistic Sources of Meaning] (pp. 17-39). Amsterdam: SWP.

Steger, M. F., Beeby, A., Garrett, S. \& Kashdan, T. B. (2013). Creating a stable architectural framework of existence: proposing a model of lifelong meaning. In I. Boniwell, S. A. David \& A. C. Ayers (eds.), Oxford Handbook of Happiness. Available on www.oxfordhandbooks. com (Accessed: May 23, 2018).

Van Praag, J. P. (1982). Foundations of Humanism. Buffalo, NY: Prometheus Books.

Von Faber, M., Bootsma-Van Der Wiel, A., Van Exel, E., Gussekloo, J., Lagaay, A. M., Van Dongen, E., Knook, D. L., Van Der Geest, S. \& Westendorp, R. G., (2001) Successful aging in the oldest old: Who can be characterized as successfully aged? Archives of Internal Medicine 161(22): 2694-2700.

Watkins, P. C. \& McCurrach, D. (2017). Progress in the science of gratitude. In C. R. Snyder, S. J. Lopez, L. M. Edwards \& S. C. Marques (eds.), The Oxford Handbook of Positive Psychology ( $3^{\text {rd }}$ ed.). Oxford University Press. Available on www.oxfordhandbooks.com (Accessed: May 23, 2018).

Weiss, R. (1973). Loneliness: The Experience of Emotional and Social Isolation. Cambridge, MA: MIT Press. 
International Journal of Ageing and Later Life

WHOQOL Group (1998). Development of the World Health Organization WHOQOL-BREF quality of life assessment. Psychological Medicine 28(3): 551-558.

Wolf, S. (2010). Meaning in Life and Why It Matters. With Commentary by J. Koethke, R. M. Adams, N. Arpaly \& J. Haidt. Princeton, NJ: Princeton University Press.

Wong, P. T. P. (ed.) (2012). The Human Quest for Meaning: Theories, Research, and Applications. New York, NY: Routledge.

Zweifel, P., Felder, S. \& Meiers, M. (1999). Ageing of population and health care expenditure: A red herring? Health Economics 8(6): 485-496. 